Для цитирования: Экономика региона. - 2015. - №4. - С. 158-169.

For citation: Ekonomika regiona [Economy of Region]. - 2015. — №4. - pp. 158-169.

doi 10.17059/2015-4-13

UDC $368.914,369$

S. A. Belozyorov, Zh. V. Pisarenko

Saint-Petersburg State University (Saint-Petersburg, Russian Federation)

\title{
PENSION REFORMS IN COUNTRIES WITH DEVELOPED AND TRANSITIONAL ECONOMIES
}

The subject matter of the research is as follows: pension reforms conducted by some states define the transformation of pension systems. The choice of countries is stipulated by the fact that each of them has different types of pension systems and preconditions for reforms. The purpose is to develop an approach that allows comparing and evaluating changes in disparate systems. The hypothesis is that the ongoing pension reforms, regardless of initial conditions and their type lead to a similar trajectory of pension systems development in all countries. The methodology rests on the comparative analysis that was carried out on the basis of a single algorithm that allows to determine significant modifiable parameters and the overall direction of reform. The novelty is that the authors research the ongoing pension reform from the viewpoint of pension rights formation and distribution of risks. The results are a single trajectory of reforms implementation for the studied countries, which confirms the authors' hypothesis. The specific features of the Russian pension system do not affect the reform trajectory, which is similar to all countries. The conclusions are the following: the reducing pressure on pension system requires increasing revenues and limiting the number of potential participants. This is achieved by expanding sources of financing, increasing the dependence of pension on an employee's contributions, transferring the risks of old age into the individual level, and employment motivation during the retirement period. The principle of the intergenerational solidarity loses its value. The obtained results can be used for the pension reform modification in the Russian Federation, the development of voluntary pension insurance based on the experience of other countries and risks faced by the modern Russian pension system.

Keywords: pension reform, scenarios of pension reforms, pension system, pay-as-you-go system, defined benefit, defined contribution, poverty protection, income replacement, pension rights, risks, pension schemes

\section{Introduction}

Many governments have been actively reforming their national old age protection systems, recently. Depending on a selected scenario, there could be defined the following types of the reforms: 1) modification requirements to a person for future pension amount without changing structure of the pension; 2) a shift from pay-asyou-go to funded schemes with focus on modernizing the proportion between the structural parts of pension payments (Latvia, Sweden, Poland, France, Mongolia, Kyrgyzstan); 3) a transition to fully funded system (Bolivia, Mexico, Chile, Salvador and Kazakhstan); 4) mixed reforms integrating all three above mentioned types (the UK, Italy, Germany, Russia).

The current form of pension system (pay-asyou-go, funded, notion-defined contribution), the social and retirement legislation, the national financial market development and the reform goals determine the choice of a reforming path. We can

\footnotetext{
${ }^{1}$ @ B Belozyorov S. A., Pisarenko Zh. V. Text. 2015.
}

underline the basic aims of the current pension reforms:

1. The setting-up of economic and socially sustainable pension system.

2. The elaboration of the flexible mechanism adapted to the individual needs of participants (the period of transition from employment to retirement).

3. The motivation to continue employment during the retirement period.

4. Equitable resources division and gender equality.

5. The development of the system based on simple and understandable rules for low educated users.

6. The availability and transparency of the information about the system operation.

The difficulty is a selection of a transition scenario: it depends on a reform type. As the population is convinced that to maintain an adequate level of living for retirees is a natural obligation of the government, and all changes are perceived ambiguously [1]. 
The purpose of the article is to formulate an approach for comparison and assessing the current pension reforms in the initially disparate systems on the common criteria. That will help to put forward suggestions for future improvement of the RF pension system.

The recent pension reforms are of research's much attention. For example, Axel H. BörschSupan [2] gives an overview of European reforms with a special attention to particular elements in the context of the world economic crisis. Edgar Vogel, Alexander Ludwig analyze pension reforms from the position of stochastic overlapped generation model [3].

The international organizations such as OECD, the World Bank, the International Labour Organization provide peer reviews of pension reforms. Under the auspices of them, annual reviews of pension and insurance markets, pension systems reforms in the world are published. The Russian authors also conduct in-depth analyses of the recent pension reform in Russia [4-8] but existing analytical frameworks do not seem to provide a full picture, as they are rather fragmentary.

\section{Theoretical frameworks}

From the focus of redistribution, the state pension policy is a dynamic system that transfers a part of individual's income during the life cycle and manages the risk of poverty in old age. Formation of pension rights is initially based on the citizenship. Thereafter, individual contributions to the system, employment period, and etc. are counted. At the payout stage, accumulated pension rights are distributed.

The authors distinguish the following types of pension rights formation:

1. Supporting - based on the current income and the subsistence minimum. It is assumed that an individual's income is below the statutory level. The supporting type performs the function of the State on poor prevention.

2. Proportional - based on the fixed percentage from a previous wage (lost income). Calculations of pension entitlements are determined proportionally to the wage during a specific period. There is a probability that the chosen period would not be the most favorable for an individual income that will result in reducing the basis for calculating the future pension benefits.

3. Tunnel - based on a stipulated minimum and maximum wage and the length of a contribution period to the system. The tunnel type suggests the linkage between contributions and subsequent pension benefits of participants. There is a possibility to earn pension entitlements within a minimum and maximum statutory limit, but the maximization of pension rights for a future retiree is restricted.

4. Equivalent - based on contributions to the system and life expectancy ('Defined Contribution' and 'Notion Defined Contribution' pension plans are close to this type). The equivalent type suggests the link between contributions and pension benefits for each worker without any restrictions on pension entitlements. As a result, the present value of expected lifetime contributions must be equal to the present value of expected lifetime benefits, which corresponds to both the principles of financial equivalence and actuarial principles.

Worldwide pension-reforming processes exactly aim to develop the models with individually dependent contributions and benefits. The variation of the equivalent type is Notional Defined Contribution (NDC) plan that combines elements of funded (DC) and unfunded (pay-as-you-go financing) plans. The pioneers in developing NDC schemes were Sweden, Poland and Latvia. Germany joined later but achieved good results [9; 10].

In NDC plans, worker's pension benefits are calculated on the aggregated individual basis revalued at a current rate of return, which is specified by either the GDP growth rate, wage growth or the combination of both. We should note that unlike the traditional funded plans, the accumulated funds are not invested but indexed on a chosen parameter (mostly with the reference to the wage growth, in percentage).

"Old age" risk management. The modern pension provision systems were developing throughout the twentieth century and were the essential element of the public management of social risk. Owing to the market failures management of old age risk was transferred from the individual level to the public one [11]. The logic of negative externalities justified the interference into privacy, and the emergence of pension arrangement institute based on the principles of risk pooling and inter-generation solidarity was an appropriate method of managing old age risk. The state pension system was aimed at managing, organizing and redistribution of resources between generations for reducing individual risk of old age poverty [12]: on one side, to provide a statutory retiree subsistence minimum above the threshold of poverty, on the other side, to maintain an acceptable living standard. There are several origins of the decline in the living standards during the retirement period for an individual. The first one is making impropriate decisions as well as overestimating his or her possibilities. Some people 
are not able to plan sufficient retirement savings due to the lack of funding; others prefer current consumption to the long-term savings. The second reason is external political, macroeconomic, demographic and other shocks, which could influence the safety of savings. All above-mentioned ones have generated the necessity for the pension schemes development with the mandatory participation of working population (in other words, taxpayers). Those patterns provided poverty risk distribution among the entire working population and guaranteed pension provision at least at the subsistent minimum of a retiree. However, in the late twentieth century a changing environment had been provoked by demographic problems in pension systems based on intergenerational solidarity. In addition, there were threats of manipulation with "social" funds for political purposes. [12].

The transferring of old age risk into the individual level reduces the probability of political risks and demographic problems but increases the risk of employment. Low salary, interruptions in working history and informal employment do not let a worker accumulate sufficient pension rights and diminish welfare at an elderly age. Crisis periods in economics result in low economic growth, high inflation rate and reduce the efficiency of funded pension plans. In addition, risks of inadequate regulation of insurance and pension markets emerge. All risks are born individually, and overall picture of the pension system is appropriate. Thus, on the basis of current pension reforms, we will analyze the way of pension entitlements accumulation and risk allocation among the system stakeholders.

\section{Methodology and research data}

Based on the World Bank ${ }^{1}$ universal classification of pension pillars, the authors conducted the comparative analysis of pension reforms in Russia, the UK, Germany, Italy and Poland, and presented the results. According to the goal of the article, the authors had formulated the hypotheses: pension system-reforming process regardless of the initial starting point, and the type of the reform leads to the similar trajectories of the pension system de-

\footnotetext{
${ }^{1}$ The World Bank classification is based on multi-pillared approach. A zero pillar is to all of the elderly. It is non-contributory and financed from the tax revenues; a mandatory earnings-relating first pillar with the objective to replace a part of the lost income. Second pillar is a mandatory funded pension based on accumulated both by employers and employees funds in the accounts of autonomous (non-state) pension funds or insurance companies; a funded voluntary third pillar and a fourth pillar - voluntary informal family support.
}

velopment. Historically, the diverse pension systems and different starting points stipulate the choice of countries for analysis. The research direction is worker's pension entitlements accumulation and the old age risk management. The distinctive feature of the approach is its focus on the proposed results of pension entitlements accumulation and redistribution of pension plan risks between the government, an employer and an employee, rather than on quantitative analysis and restructure of the administration of revenues.

\section{Empirical results}

The pension system in the Great Britain consisted of three main pillars (table 1): The Basic State Pension Pillar, The State Earnings Related Pension Pillar and Corporate Pension Pillar ${ }^{2}$. However, an outdated design failed to meet today's economic realities.

Started in 2015, the pension reform will fundamentally change pension system in the UK. On the lower pillars, there are risks of fiscal sustainability of the system (borne by the state and an employer, they have partly shifted to an employee). Risks of funded DC plans have been fully borne by an individual. The system has been transformed into an equivalent type.

The essence of the new policy is a consolidation of citizens' retirement accounts into a new united structure, i.e. syndicated pension funds for workers. The collective form of pension plans will supplement the private funded pension schemes. Concurrently, limits to tax-free salary will increase up to $£ 15,000$ per year. The new program is close to the equivalent type of the pension rights accumulation. There are several variants of disposal of individually accumulated pension pot: a retiree can withdraw $25 \%$ of accumulated amount taxfree. If the amount of the pension pot is less than $£ 18,000$, the rest $3 / 4$ parts (after the withdrawal) could be got after reduced income tax, more, the income tax rate will be $55 \%$. One more way is an insurance market mechanism: it is possible to buy an annuity (the right for a lifetime income). The amount of annuity will make up a certain percentage of the pension pot. The third variant is an investment income on an accumulated fund (not the percentage of the amount). This variant is possible in case of a large amount of accumulated funds and when the investment income is more than annuity amount ${ }^{3}$.

\footnotetext{
${ }^{2}$ Finance Act (FA) 2004. Part 4. Retrieved from: https://www. gov.uk/government/uploads/system/uploads/attachment_data/ file/385065/TIIN_8130_2140.pdf (date of access 26.06.2015).

${ }^{3}$ Retrieved from: https://www.gov.uk/plan-retirement-income/ private-pensions (date of access: 22.06.2015).
} 
The pension reform in the United Kingdom

\begin{tabular}{|c|c|c|}
\hline $\begin{array}{l}\text { The Pillars of Pension } \\
\text { Provision }\end{array}$ & Pre-Reforming Structure & Post-Reforming Structure \\
\hline $\begin{array}{l}0 \text {-pillar (social } \\
\text { pensions) }\end{array}$ & $\begin{array}{l}\text { A. Minimal Income Guarantee (supporting type, } \\
\text { means tested). } \\
\text { B. Pension Credit (DB - Defined Benefit, budget } \\
\text { financing, means tested). } \\
\text { C. Basic State Pension (DB - Defined Benefit, } \\
\text { supporting type, administratively established size) }\end{array}$ & $\begin{array}{l}\text { B. Pension Credit (DB - Defined Benefit). } \\
\text { For people on a low income }\end{array}$ \\
\hline \multirow{2}{*}{$\begin{array}{l}\text { 1-st pillar } \\
\text { (pay-as-you-go) }\end{array}$} & $\begin{array}{l}\text { SERPS (State Earnings Related Pensions), DB } \\
\text { (Defined Benefit, inter-generation risk distribution } \\
\text { (until 2002) }\end{array}$ & \multirow{2}{*}{$\begin{array}{l}\text { Single Pension Scheme, based on } \\
\text { redistribution of individuals' income, inter- } \\
\text { generation solidarity (New State Pension if } \\
\text { a person reaches State Pension age after } 6 \\
\text { April 2016) }\end{array}$} \\
\hline & $\begin{array}{l}\text { S2P (The State Second Pension), replaced SERP } \\
\text { (DB - Defined Benefit, the risk distribution } \\
\text { amongst generations and employees' types }\end{array}$ & \\
\hline \multirow[b]{2}{*}{$\begin{array}{l}\text { 2-nd и } 3 \text {-d pillars } \\
\text { (funded) }\end{array}$} & \multirow[b]{2}{*}{$\begin{array}{l}\text { Corporate pension plans (DB - Defined Benefit } \\
\text { (risks borne by an employer) }\end{array}$} & $\begin{array}{l}\text { Corporate pension plans (actuarial basis, } \\
\text { DC (Defined Contribution), risks borne by } \\
\text { an employee) }\end{array}$ \\
\hline & & $\begin{array}{l}\text { Supplementary, private voluntary funded } \\
\text { plans (actuarially based, risks borne by an } \\
\text { individual, a pension pot based on how } \\
\text { much is paid in); from } 2018 \text { will become } \\
\text { mandatory }\end{array}$ \\
\hline 4-th pillar & Informal family support & $\begin{array}{l}\text { Informal family support as an extra source } \\
\text { of elderly age income }\end{array}$ \\
\hline
\end{tabular}

Composed by the authors.

The state motivates citizens to choose an appropriate variant for the pension pot disposal independently. However, there are hidden risks of poor decision-making, which could sufficiently lessen income during the retirement period of an individual ${ }^{1}$. To mitigate this risk, the Government of the UK promises a free expert advice in selecting the options of the pension pot disposal. The next task is to create the new state pension system for the least well-off retirees through the independent decision-making. The state limits a potential number of recipients with the abolition of the Second State Pension (S2P) and correspondingly the prolongation of the period of contributions to the system for five years; additionally, the Single Pension Scheme based on the redistribution of incomes through inter-generation solidarity is introduced. An extra incentive to enlarge accumulated funds will be tax repeal on the transfer of private pension savings to the heirs. However, there could be tax evasion schemes, drop in annuities sales and the implementation of the long life risk. As for the last one, the Government plans to compensate it by the informal family support. The UK Government pays special attention to the

\footnotetext{
${ }^{1}$ Government Finance Statistics. Retrieved from: http://epp.eurostat.ec.europa.eu/portal/page/portal/government_finance_ statistics/documents/PL-Ex-ante_consultation-Subaccounts. pdf (date of access: 26.06.2015).
}

pension insurance products that are provided by autonomous pension funds, as there is a way to access well-diversified UK insurance and reinsurance markets.

Pension reform in Germany. Three pillars pension insurance system in Germany was established mostly on the pay-as-you-go principle. The state pension schemes prevailed while funded plans were of secondary importance. Therefore, the German Government made the main emphasis on the pay-as-you-go pillar reforming towards more flexibility, considering employment history and contributions made to the system. All mentioned above should change the proportion between structural parts of pension benefits. This scenario is of the second type.

Pension reform of "The Grand Coalition" entered into force on June 2014. ${ }^{2}$. It is laid on four principles: early retirement on a full pension at the age of 63 , maternity pension, partial disability pension and rehabilitation budget (der Bemessung des Rehabilitationsbudgets) (table 2).

The key emphasis of the coalition reform is made on the duration of a contribution period with the simultaneous reduction of preferences $(a$

\footnotetext{
2 Entwurf eines Gesetzes über Leistungsverbesserungen in der gesetzlichen Rentenversicherung (RV-Leistung sverbesserungsgesetz). Retrieved from: http://dip21.bundestag. de/dip21/btd/18/015/1801507.pdf (date of access: 26.06.2015).
} 
The current pension reform in Germany

\begin{tabular}{|l|l|l|}
\hline Pillars of Pension Provision & \multicolumn{1}{|c|}{ PreReforming Structure } & \multicolumn{1}{c|}{ Post-Reforming Structure } \\
\hline 0-pillar (social pensions) & Social allowances (budget financing) & $\begin{array}{l}\text { Social allowances (budget financing) } \\
\text { Mandatory elderly age pension }\end{array}$ \\
\hline \multirow{2}{*}{ 1-st pillar (pay-as-you-go) } & $\begin{array}{l}\text { Mandatory elderly age pension (DC - } \\
\text { Defined Contribution, risks are shared } \\
\text { between a worker, an employer, and the } \\
\text { state; calculation in pension points) }\end{array}$ & $\begin{array}{l}\text { Early retirement on the full pension at 63 (for } \\
\text { those born on or before 1953) } \\
\text { Maternity pension } \\
\text { Disability pension } \\
\text { (DC - Defined Contribution, risks are shared } \\
\text { between a worker, an employer, and the state; } \\
\text { calculation in pension points) }\end{array}$ \\
\hline 2-nd и 3-d pillars (funded) & $\begin{array}{l}\text { Corporate pension plans (DB - Defined } \\
\text { Benefit (risks borne by an employer)) }\end{array}$ & $\begin{array}{l}\text { Corporate pension plans (DB - Defined } \\
\text { Benefit (risks borne by an employer)) }\end{array}$ \\
\cline { 2 - 3 } & $\begin{array}{l}\text { Private voluntary plans actuarial basis, } \\
\text { risks borne by an employee }\end{array}$ & $\begin{array}{l}\text { Private voluntary plans actuarial basis, risks } \\
\text { borne by an employee }\end{array}$ \\
\hline 4-th pillar & Informal family support & $\begin{array}{l}\text { Informal family support as an extra source of } \\
\text { elderly age income }\end{array}$ \\
\hline
\end{tabular}

Composed by the authors.

higher education period is excluded from the contribution period, although in 1991, it was 13 years). Early retirement is allowed in case of the working period record of 45 years without claiming unemployed benefits for more than a short time.

The next phase of the reform is increasing contributions to Pension Fund and reducing the replacement rate for the lost earnings. Contributions will smoothly rise from $18.9 \%$ up to $22 \%$ of salary, the average pension size will have been counted only $43.7 \%$ of the lost earnings in 2030 (today the average replacement rate is $49.6 \%$, it was $52.9 \%$ in 2000). We should note that this scenario is possible only under relatively stable economic conditions and a low unemployment rate.

Developed economies, including Germany, are characterized by the outrunning growth of population aged over 80 years; an individual faces the risk of long life. As the OECD estimates, by 2050, the old-aged population will have tripled. The German dependency ratio will have been among the highest in the world. Therefore, it is essential to encourage people to enter funded pension plans founded on actuarial principles as well as to rely on the informal family support ${ }^{1}$. Each of these sources contributes to the result.

Thus, there will be a significant expansion of the pension provision pillars in the nearest years, the reduction of the state pensions amount regardless of the level of earnings, the shift to funded pension plans, and wider old age risk transfer into an individual.

\footnotetext{
${ }^{1}$ Pension Markets in Focus. OECD. 2014. Issue 7. Retrieved from: www.oecd.org/daf/pensions/pensionmarkets (date of access: 26.06.2015).
}

Pension reform in Italy. The Italian pension system as Germanys is mostly grounded on a pay-asyou-go basis. According to estimations, the proportion of the state pension payments was about $70 \%$ of the total amount of the pension received by an employee. The major source of private pensions is autonomous pension funds and insurance companies, which correspondingly provide about $30 \%$ and $18 \%^{2}$.

"The Fornero pension reform" in Italy came into force in 2012 (DL 201/2011 - Decreto-Legge 6 dicembre 2011, № 201), ${ }^{3}$ assuming the transition to the NDC system (the second type of the reform). The first component of the reform is gradual increasing of the statutory retirement age by establishing a minimum contribution period of 20 years and the eliminating gender gap age by equalizing the retirement age for men and women. By 2018, the statutory retirement age in Italy will have been 66 years and six months for both genders.

The second component is that early retirement will replace the elderly age state pension (Pensione Sociale). Employment history for early retirement must be at least 41 years and six months for women and 42 years and six months for men (in 2014-2015). The third component is an annual periodical recalculation of retirement age depending on an increase in average lifespan (table 3).

\footnotetext{
${ }^{2}$ Pension Markets in Focus. OECD. 2014. Issue 7. Retrieved from: www.oecd.org/daf/pensions/pensionmarkets (date of access: 26.06.2015).

${ }^{3}$ Factbox: The Fornero pension reform law. Retrieved from: http://www.ansa.it/english/news/politics/2015/01/20/factboxthe-fornero-pension-reform-law_41db6dc8-72e8-4b27-a0112dae8da54403.html (date of access: 26.06.2015).
} 
The scheme of Pension Reform in Italy

\begin{tabular}{|l|l|l|}
\hline Pillars of Pension Provision & \multicolumn{1}{|c|}{ Pre-Reforming Structure } & \multicolumn{1}{c|}{ PostReforming Structure } \\
\hline 0-pillar (social pensions) & Not provided & $\begin{array}{l}\text { Assegno Sociale (social allowance) - means tested, } \\
\text { risks borne by the state }\end{array}$ \\
\hline 1-st pillar (pay-as-you-go) & $\begin{array}{l}\text { Pensione Sociale (social pension) } \\
\text { - minimum elderly age pension }\end{array}$ & Not provided \\
\hline 2-nд и 3-d pillars (funded) & $\begin{array}{l}\text { Social insurance system Sistema } \\
\text { Retributivo (earning related } \\
\text { methodology) - basis: average } \\
\text { salary) }\end{array}$ & $\begin{array}{l}\text { NDC (Notion-Defined System) } \\
\text { Metodo Contributivo (contribution based } \\
\text { methodology - actuarial basis, risks are divided } \\
\text { among an employer and an employee }\end{array}$ \\
\cline { 2 - 3 } & $\begin{array}{l}\text { Voluntary system, autonomous pension funds, } \\
\text { (actuarial basis, risks borne by an employee) }\end{array}$ \\
\hline 4-th pillar & Informal family support & $\begin{array}{l}\text { Informal family support as an extra source of elderly } \\
\text { age income }\end{array}$ \\
\hline
\end{tabular}

Composed by the authors.

Table 4

Pension reform in Poland

\begin{tabular}{|l|l|l|}
\hline Pillars of Pension Provision & \multicolumn{1}{|c|}{ Pr- Reform Structure } & \multicolumn{1}{c|}{ Post-Reform Structure } \\
\hline \multirow{2}{*}{$\begin{array}{l}\text { 1-st pillar } \\
\text { The minimal pension } \\
\text { provision }\end{array}$} & $\begin{array}{l}\text { Mandatory elderly age pension } \\
\text { (DC - Defined Contribution) } \\
\text { risks borne by employees } \\
\text { according to a type of } \\
\text { employment }\end{array}$ & $\begin{array}{l}\text { 0-ties - guaranteed minimum pension (means } \\
\text { tested, a supported type, risks born by the state) }\end{array}$ \\
\cline { 3 - 3 } 2-nd pillar social insurance & $\begin{array}{l}\text { 1-st pillar - mandatory pension (DC - Defined } \\
\text { Contribution, inter-generation risk distribution, } \\
\text { earning and employment period related) }\end{array}$ \\
\hline $\begin{array}{l}\text { Pension programs (DB - } \\
\text { Defined Benefit (inter-generation } \\
\text { solidarity) }\end{array}$ & $\begin{array}{l}\text { 2-nd pillar - mandatory funded (DC - Defined } \\
\text { Contribution (actuarial basis, risks borne by an } \\
\text { employee) }\end{array}$ \\
\cline { 3 - 3 } & $\begin{array}{l}\text { 3-rd pillar - Voluntary private pension programs } \\
\text { (actuarial basis, risks borne by an employee) }\end{array}$ \\
\hline
\end{tabular}

Composed by the authors.

The Italian pension system has become closer to the liberal model, typical for Britain. There have been fines for early retirees recently: $2 \%$ each year until reaching the age of 60 and $1 \%$ - after 60 . For 2015-2017, early retirement fines were canceled. This element is similar to the German pension reform: an early retirement, a subject to the payment of contributions to the Pension Fund no less than 20 years ${ }^{1}$.

As the authors suggest, the NDC pension reform path is rather a good compromise for Italy between Defined Contribution and Defined Benefit pension schemes. Risks of adequate financing of the system are fully borne by a future retiree. Unfunded schemes, on the contrary, transfer risks to the state. From the view point of a financing mechanism, unfunded schemes (pay-asyou-go) are determined by demographic, macroeconomic and other parameters. The compromise allows distributing risks for a wide range of partic-

\footnotetext{
${ }^{1}$ The consultative site devoted to the social insurance and pension reform in Italy. Retrieved from: www.inps.it (date of access: 26.06.2015).
}

ipants and, as a result, reducing the risk for an individual. However, individually borne risks are still the ones of low wages, employment breaks or early retirement. Since the calculation of payments is based on the previous employee's contribution to the system (not based on available resources in the system at the time of retirement), there is a probability of funding gap risk, which will be eliminated at the expense of working population.

Pension reform in Poland. Central and Eastern Europe and the post-Soviet countries have faced the problem of the transition from the centralized social provision to the social insurance system. Eastern Europe is an illustration of the funded pension system failure. Unlike Russia, where pension savings are "frozen", in several countries of Eastern Europe accumulated savings were nationalized and spent by the Government.

A large number of financial institutions pension funds and insurance companies - had emerged during the post-Soviet transition and privatization of the state property in Poland. After insurance and pension markets formation had been completed, a rapid consolidation started. New for- 
eign financial institutions came to the market that changed radically the balance of power in the financial industry [13].

The pension reform in Poland had already started in 1999 during the country's transition to the market economy. Future pension benefits became dependent on the amount of individual contributions made during the employment period (table 4).

The prevailing idea of the reform was the thesis about the need to diversify the sources of pension contributions, which included two mandatory and one voluntary pillar. Mandatory pillar constituted $19.52 \%$ of the payroll. On the first stage, funds were transferred to the accounts of the State Social Insurance Fund (ZUS - Zakład Ubezpieczen Społecznych), and then $7.3 \%$ of the overall amount were transferred to autonomous pension funds. The citizens were to choose the pension fund, which invested into an accumulative part of the future pension. The third pillar is voluntary individual retirement accounts. The total amount of accumulated funds was the largest among the East European countries - about 70 billion euros of assets with more than 16 million participants. However, at the end of 2013, the Government nationalized $51.5 \%$ of the non-state pension funds assets ${ }^{1}$. Funds were transmitted to The State Pension Fund from mandatory funded pillar to the unfunded pillar with annual indexing on nominal GDP growth rate $^{2}$. Elderly participants (10 or fewer years before the pension) were required to transfer their savings from non-state funds to The State Pension Fund, and the others were obligated to make a choice either to stay in the mandatory system or to select a combination of both. In addition to the narrowing of the $\mathrm{cu}-$ mulative component, the government proposed a gradual increase in the retirement age up to 67 years (from 60 for females and 65 for males). This reflects the Poland's path to the harmonization with the European countries on the issue of gender equality. However, the new statutory retirement age escalated social tensions in the country and did not lead to the set objectives.

Following the running out of the withdrawn pillar money, there will be an inevitable extra bur-

\footnotetext{
1 European Commission Letter. Retrieved from: http:// ec.europa.eu/eurostat/documents/1015035/2990403/PLReply-to-ex-ante-consultation-related-to-systemic-pensionreform-27-11-2014.pdf/86c08827-225f-4231-9f74-be6c2e7b9e1a (date of access: 28.06.2015).

${ }^{2}$ Government Finance Statistics. Retrieved from: http://epp.eurostat.ec.europa.eu/portal/page/portal/government_finance_ statistics/documents/PL-Ex-ante_consultation-Subaccounts. pdf (date of access: 26.06.2015).
}

den on the working population and further questions about the necessity of funded pillar refusal. For instance, with the similar scenario, the Czech Republic has already faced the problem of raising payroll taxes to finance the state social provision system. The inertia of the economy and pension systems does not allow fully assessing the consequences of any failure of the funded component ${ }^{3}$. Tactically, the government decision to use accumulated funds (about 50 billion Euros) to cover the budget deficit and to solve urgent tasks was correct. Before the withdrawal, the budget deficit amounted to $5 \%$. In 2014, the budget surplus was about $4.5 \%^{4}$. However, strategic thinking shows future defeat: the country will lose a vast source of cheap domestic investments, and citizens - the chance to increase their well-being in elderly age.

Pension reform in Russia. For a proper and deep analysis of the Russian retirement system we should point out general problems determined the whole series of ongoing reforms. Firstly, a fundamental challenge of the Russian retirement system is the long-term budget deficit of The State Pension Fund (PFR) (figture 1). It influences the financial stability of the state pension commitments and requires an increased share of GDP to cover the deficit. If, in the medium-term period between 2020 and 2030 it will have amounted just over $5 \%$, in the long-term, the expected share of GDP will have exceeded $20 \%$. The short-term deficit reduction of the PFR in the period from 2020 to 2030 has been determined by a new phase of pension reform, started in 2014.

Secondly, another square circle is the demographic characteristics of Russia. According to the decline rate of the working-age population (about $1 \%$ per year), Russia will have been among top ten countries in the world in the next 15 years. However, Russian aging is less deep and, unlike the European one, tends to increase the number of "young" retirees. Even by 2050 under the UN estimations of the proportion of the Russians aged over 80 years will have been only $6 \%$ of the total population. Thirdly, an acute problem in the Russian pension system is poor financial literacy of the population and a lack of trust in long-term financial projects. That is the repercussion of the

\footnotetext{
${ }^{3}$ The electronic version of bulletin "The Population and Society". Institute of Demography - National Research University Higher School of Economics. Retrieved from: http://www.demoscope.ru/weekly/2014/0623/gazeta021.php (date of access: 26.06.2015).

${ }^{4}$ Government Finance Statistics. Retrieved from: http://epp.eurostat.ec.europa.eu/portal/page/portal/government_finance_ statistics (date of access: 26.06.2015).
} 


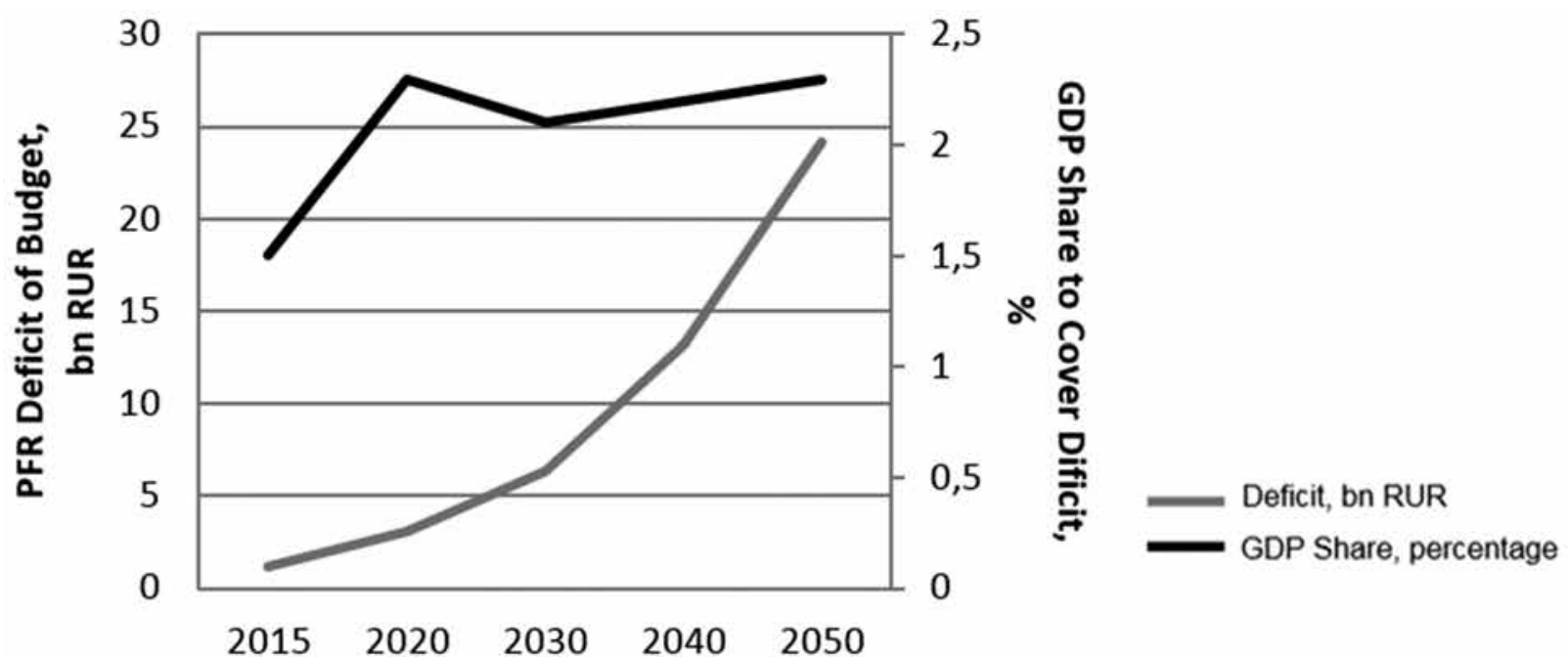

Fig. 1. The estimated PFR budget deficit for the period up to 2050 (compiled by: the FL dated 03.12.2012 \# 218-FL "On the Budget of the Russian Federation Pension Fund of 2013 as well as the planned period of 2014-2015 years"; the forecast of the Ministry of the Russian Federation Economic Development, dated 13.04.2012)

negative experience of 20 -year transition period [14].

Old age poverty is also a topical problem in Russia. The minimum replacement rate adopted in the world practice is $40 \%$ of the previous income. The same is for Russia. The national average replacement rate is $47 \%$; however, it reaches $70 \%$ in some regions. We can see the Russian specificity here: in the regions with the maximum replacement rate, the average salary barely exceeds the minimum subsistence level. In 2013, in the Ivanovo region, it was 16200 rubles, in the Kostroma, Bryansk, Kursk regions - just above 17000 rubles. The minimum average wage was recorded in the Orlov region, and it amounted to 13300 rubles, maximum - in Chukotka Autonomous District and Moscow (50400 rubles). Indeed, the Orlov region replacement rate reached almost $78 \%$ (the national average pension benefit constituted 10400 rubles in 2014), and in Moscow was only $21 \%$. Such regional disparities are typical for Russia; therefore, it is unacceptable to use average indicators in our country. The authors suggest a unified criterion of pension benefits amount. It should be elaborated by the expert community taking into account the specifics of the regional development in Russia.

The solution for the old age poverty problem in Russia could be found in the long-term perspective with the individualization of the funded part of pension contributions. Russia also should use the accumulated international experience of reforms with consideration to its specificity: the statutory retirement age rise (the use of the phrase "encouraging later retirement" is more socially approved) as well as encourage the development of voluntary pension plans and pension in- surance. All the above-mentioned solutions to the problems of the pension system will economically affect only in the medium and long-term. It is necessary to analyze risk factors and drivers of pension system financial sustainability in the nearest future.

Informal labour market. Hidden remuneration schemes are a risk factor for The State Pension Fund revenues and replacement rate decrease during the retirement period. It is possible to determine the scale of the informal labor market and the size of the shadow financial flows only on the indirect data. But the a non-observed economy is a huge reserve for the effective development of countries with economies in transition [15]. It could be used by improving the democratic foundations and the institutional framework of the market economy. Despite significant growth in monetary terms, the share of hidden remuneration has not practically changed since the period from 2000 to 2010 , and it is more than $50 \%$ of the payroll that stands for stable and mature informal sector in the RF economy. The estimated lost contributions in 2013 were more than 1.4 trillion rubles. That is especially important, as the budget deficit in 2013 was 1.99 trillion rubles.

The widespread of informal employment along with low wages is usually seen as a temporary result of the economic transformation. However, the experience of Western countries that entered the path of post-industrial development earlier suggests that the increasing diversity of employment types and changing employment behavior are inseparable companions of the progress.

Pension systems are under profound impact today; as they were organized to cover risks of old age for industrial workers, with employ- 
ment throughout the life under conditions of full employment ${ }^{1}$.

The research on forms of informal employment conducted by the group of the authors [16] proves that risks are inversely proportional to a size of an enterprise and in the service sector, and construction business is higher than in industrial enterprises. Similar results [17] are given by the study of informal employment that is common for self-employed individuals in small businesses.

Consequently, decreasing figures of employees on large- and medium-sized enterprises and growth of employment in the informal sector can be seen as processes that reduce the number of potential payers of pension contributions. It is important to realize that the most reliable information on wages is also collected primarily from large and medium-sized enterprises, and their share has been steadily declining. Based on the provided information, the average wage and the replacement rate (the ratio of the average pension to the average wage) are calculated.

State employee transfers. In 2011, the number of the state employees in Russia amounted to 1.114 million workers. The average salary of officials was more than the third (35.6\%) higher than the average salary in Russia. According to the State Statistics Committee, in 2014, 4 million people served in Russian law enforcement agencies: 1.32 million people were police officers, 2.02 million people worked in the Ministry of Defense, 325.5 thousand people - in the Federal Service for Execution of Punishment, 40 thousand people - in the Federal Drug Control Service. The authors suggest that there are reasons to consider the extension of the pension insurance system to all categories of employed persons (civil servants, military and law enforcement officials in the relevant law enforcement agencies, on the analogy with the civil officers, who are subject to obligatory pension insurance). The beneficial aspect is that the average age of civil servants is $39-40$ years. Pension contributions will be paid from now on. However, the payout period will come only in $20-25$ years. The inclusion of state servants in the system of pension insurance will enable to reduce the risks of imbalances significantly in the budget of the Pension Fund of the Russian Federation. The advantage is also the fact that there is informal employment among state servants.

Low financial literacy of the population. The USSR system did not require the enrollment of a

\footnotetext{
The Unified Inter-department Federal Statistic Service. "Hidden labor payment and mixed incomes". Retrieved from: http://fedstat.ru/indicator/description.do?id=33977 (dae of access: 20.03.2015).
}

citizen in the process of the future pension formation. There are the following problems faced by the state owing to the remnants of the former USSR system:

1) the lack of the habit to make decisions upon personal risks;

2) incredulity to the financial market;

3) underdeveloped financial markets and the lack of capital;

4) the comparative advantages of the former monopoly over newly created competitors;

5) the absence of the historical data about losses of non-state pension funds and information about companies;

6) the lack of supervision and market regulation;

7) the lack of infrastructure.

The negative experience of financial pyramids, transition to the market economy, devaluation of the national currency, loss of savings, and etc. worsen the situation. For decreasing The State Pension Fund deficit, it is necessary to create incentives for the population to participate in voluntary pension schemes of autonomous pension funds and insurance companies. The latter should have an access to conduct operations in the mandatory pension system.

The necessity for regulation and supervision consistency. Since the pension system transformation was launched in 2002, the current reform has been the third one. That causes reasonable concerns for future retirees as the mandatory pension insurance requires the contributions of the economically active part of the population throughout their employment period. The created three pillars pension system combined the mandatory participation in the pay-as-you go system (1st pillar), the mandatory funded 2nd pillar and voluntary pension savings (3rd pillar). Recently, it has been again under the revision and transformation (table 5).

After the next phase of the pension reform, the emphasis of the regulator has changed: the cumulative element is out of attention, vulnerable to criticism. The government intends to exclude the funded system out of the obligatory pension insurance. The existing accumulated funds are "frozen" until the end of 2015 and transferred to the unfunded system to repay The Pension Fund deficit. This means that the priority for the regulator (as in the countries with transitional economies) is to solve short-term problems of the RF pension system. Moreover, the complex mechanism of pension calculation has become more complicated: instead of the usual cash form, it is based now on pension points. Pension entitlements are 
Pension Reform in Russia

\begin{tabular}{|l|l|l|l|}
\hline $\begin{array}{c}\text { Pillars of Pension } \\
\text { Provision }\end{array}$ & Pre-Reform Structure & Post 2002-2006 Reform Structure & Post 2015 Reform Structure \\
\hline $\begin{array}{l}\text { 0-pillar (social } \\
\text { pensions) }\end{array}$ & Not provided & $\begin{array}{l}\text { Elderly age pension (independent } \\
\text { of the employment period, indexed, } \\
\text { appointed in 5 years after statutory } \\
\text { pension age) }\end{array}$ & $\begin{array}{l}\text { Fixed payment independent } \\
\text { of the employment period, } \\
\text { indexed }\end{array}$ \\
\hline $\begin{array}{l}\text { 1-st pillar } \\
\text { (pay-as-you-go) }\end{array}$ & $\begin{array}{l}\text { Elderly age pension (pay- } \\
\text { as-you-go), personal } \\
\text { pensions (personal merits) }\end{array}$ & $\begin{array}{l}\text { Obligatory labor pension (fixed basic } \\
\text { amount of an insurance part + labor } \\
\text { pension) (pay-as-you-go, earning } \\
\text { and employment period related, } \\
\text { indexed, risks borne by the state) }\end{array}$ & $\begin{array}{l}\text { Elderly age insurance pension } \\
\text { employment period related, } \\
\text { indexed, risks borne by the } \\
\text { state) }\end{array}$ \\
\hline 2-nd (funded) & Not provided & $\begin{array}{l}\text { Obligatory funded pension } \\
\text { (mandatory choice between the state } \\
\text { and non-state pension funds) }\end{array}$ & $\begin{array}{l}\text { Voluntary funded pension } \\
\text { of pension) risks borne by an } \\
\text { employee }\end{array}$ \\
\hline 3-rd (funded) & Not provided & $\begin{array}{l}\text { Voluntary pension plans (actuarial } \\
\text { basis, risks borne by an employee) }\end{array}$ & $\begin{array}{l}\text { Voluntary pension plans } \\
\text { (actuarial basis, risks borne by } \\
\text { an employee) }\end{array}$ \\
\hline
\end{tabular}

Composed by the authors.

* Minimum contribution period is 15 years and 30 points.

formed on the tunnel type (maximum annual income is stipulated for calculation of contributions) with equivalent type elements on the 3rd pillar. The purposes of the reform are to increase the value of the insured employment period for the employee and to individualize personal contribution to the system. The overall direction of the reform coincides with the reform direction in the developed countries and implies a significant transfer of old age risk management into the individual level. However, the primary task is to balance the pension system by encouraging an extension of the employment period after statutory retirement age by transferring major scoring on that period without application for pension benefits. For every extra year of employment, both the fixed and insurance part of pension will increase by the corresponding coefficients. This way the regulator postpones the fulfillment of obligations to the retiree and reduces the expected period of payment.

\section{Conclusions and recommendations}

A pension reform is always a part of structural changes in economic and social policies of a state. Its main purpose is to create the multi-pillar pension system that provides citizens with the opportunity to have a decent pension after retirement. In the comparative analysis of pension reforms scenarios in the UK, Germany, Italy, Poland, and Russia we have identified several general trends:

1 . The reduction of importance for basic unfunded pension pillar in favor of higher pillars and increasing the statutory retirement age. Thus, the state separates functions of poverty protection in elderly age and the replacement of the lost income and their redistribution to different pillars of the pension provision.

2. Pension entitlements modernization takes place in the following directions:

- the poverty prevention acquires the features of the social provision, as the right to get these types of pensions is means tested and budget funding (the source is tax revenues). Risks are entirely borne by the state, and the redistribution of incomes occurs through the principle of inter-generations solidarity;

- the replacement of the lost income based on an individual contribution and the lifetime expectancy of a retiree points out the actuarial component in the calculation of future benefits. In turn, the principle of generations solidarity loses its value;

- the increasing role of funded financing, which may be implemented in various forms, from the creation and investment of insurance reserves under the state system to the complete privatization of the pension system.

3 . The common features of the analyzed reforms are the transfer of the old age risk and long life risk management from the state to the individual level.

4. The Russian pension system modification runs in parallel both with the developed and the Central and Eastern European countries, which in the early 2000s moved from centralized to market-oriented mechanisms. 
The above mentioned allows us to consider our hypothesis confirmed.

5. While defining the future direction of the Russian pension system reform, it is necessary to pay attention to both the positive and negative consequences of certain decisions:

- there are several affordable options for the UK retirees to choose from. It does not just personify the contribution of each retiree to the overall pension pot, but arises a feeling of personal involvement and could become a motivating element for additional contributions to voluntary pension programs. This experience is rather relevant for Russia, because of a high share of informal remuneration and informal employment;

- the opportunity to choose a variant of disposal for the individually accumulated pension pot requires a high level of financial literacy and responsibility for the elderly age period. They have not been sufficiently developed in our country yet;

- the German experience could be useful for reasonable flexibility of the system, considerations of individual contributions and employment history concurrently with a great share of an unfunded component;

- the possibility of early retirement with a long-term employment history is provided in Germany and Italy, which is also relevant for Russia;

- another positive experience would be the implementation of theNDC component (Italy's experience) in Russia, allowing to disperse risks for a wide range of people in the community and reduce an individual risk accordingly;

- the nationalization of accumulated funds had not solved the main problems of the Poland's pension system. However, it was one more "stain" on the reputation of the regulator. At the same time, the Russian government decided to extend the moratorium on the funded component for 2016.

The pension provision in Russia is grounded on an extensive legislative framework, currently. There is a large number of federal normative legal acts, regulating the sources for the pension provision, principles and methods of accumulation, saving and distribution of available resources. There is also a continuous improvement of the legislation. Therefore, the comparative analysis of pension reforms being simultaneously regarded with the Russian one (both for advanced economies with a long history of pension markets and countries with transitional economies) is very important for the further development of the pension system and encouraging the participation of the population.

The results could be useful in further analysis for the purpose of pension regulation improvement, because a high level of pension benefits increases the adequacy of the system, but reduces its sustainability. At the same time, the increase in the retirement age or its economic equivalent - encouraging later retirement during the growth of life expectancy - has a positive effect on its stability.

In addition, the results of the study could be useful for the insurance industry: both for insurers and regulatory agencies. The conclusions will add extra information to optimal strategic decision-making and a choice of the optimal way of the development considering external challenges. They help to offer new long-term pension insurance products with an investment component that will undoubtedly diversify the risk of pension investments by dividing them between the state, pension and insurance market.

\section{References}

1. Arza, C. (2006). Welfare regimes and distributional principles. EUU Working papers. RSCAS, 30. Retrieved from: http://cadmus.eui.eu/bitstream/handle/1814/6256/RSCAS-2006-30.pdf?sequence=1 (date of access: 12.05.2015).

2. Börsch-Supan, A. H. (2013). Entitlement Reforms in Europe: Policy Mixes in the Current Pension Reform Process. Fiscal Policy after the Financial Crisis. Alesina and Giavazzi. Retrieved from: http://www,nber.org/books/ales11-1 (date of access: 12.05.2015).

3. Vogel, E., Ludwig, A. \& Börsch-Supan, A. (2013). Aging and Pension Reform: Extending the Retirement Age and Human Capital Formation. NBER Working Paper, 18856. Retrieved from: http://www.nber.org/papers/w18856 (date of access: 22.07.2015).

4. Fomin, I. A. (2014). O strategicheskikh tselyakh pensionnoy reformy 2015 goda $v$ Rossiyskoy Federatsii [Strategic goals of the Russian pension reform 2015]. Ustoychivoye razvitie. Obshchestvo i ekonomika. Materialy mezhdunarodnoy nauchno-prakticheskoy konferentsii, posvyashchennoy 290-letiyu Sankt-Peterburgskogo gosudarstvennogo universiteta [Sustainable development. Society and economics. Proceedings of the international scientific and practical conference devoted to the 290 anniversary of the St. Petersburg State University]. In: A. V. Vorontsovskiy (Ed. in. Ch.), O. L. Marganiya, S. A. Belozerov (Eds). St. Petersburg: Sankt-Peterburgskiy universitet Publ., 333-334.

5. Shchebetun, S. Yu. (2014). Perspektivy pensionnoy reformy RF v ramkakh novogo etapa pensionnoy reformy 2014-2015 g. [Prospects of the pension system of the Russian Federation in the new phase of pension reform 2014-2015 
year]. Elektronnyy vestnik Rostovskogo sotsialno-ekonomicheskogo instituta [Electronic bulletin of the Rostov Social and Economic Institute], 3, 291-297.

6. Mikhaylova, A. V. \& Sirayeva, R. R. (2014). Negosudarstvennyye pensionnyye fondy i ikh rol v pensionnoy reforme [Nonstate pension funds and their role in pension reform]. NovaInfo.Ru, 28, 165-167.

7. Orekhov, A. A. (2014). O provodimoy reforme pensionnoy sistemy Rossiyskoy Federatsii [About the reform of pension system of the Russian Federation]. Finansovyy vestnik [Financial bulletin], 1(29), 70-75.

8. Kolyabin, A. Yu. (2015). K voprosu o strakhovom stazhe i «nestrakhovykh periodakh» v pensionnoy reforme 2015 goda [To a question of insurance experience and «not insurance periods» in pension reform of 2015]. Sotsialnoye i pensionnoye pravo [Social and pension law], 1, 15-18.

9. Legros, F. (2003, Sept. 28-30). Notional Defined Contribution: A Comparison of the French and German Point Systems. Paper presented at the World Bank and RFV Conference on NDC Pension Schemes, Sandhamn, Sweden.

10. Holtzmann, R. \& Palmer, E. (Eds). Non-Financial Defined Contribution (NDC) Pension Schemes: Concept, Issues, Implementation, Prospects. Washington D.C.: World Bank. 2005.

11. Barr, N. (2001). The welfare state as piggy bank: information, risk, uncertainty, and the role of the state. Oxford University Press, Oxford. 2001.

12. Kaplow, L. \& Shavell, St. (2003). Fairness versus Welfare: Notes on the Pareto Principle, Preferences, and Distributive Justice. Journal of Legal Studies, 1, 32(1).

13. Pisarenko, Zh. V. (2014). Institutsionalnyye osnovy razvitiya pensionnykh sistem $v$ usloviyakh finansovoy konvergentsii [Financial Convergence and the Institutional Evolution of Pension Systems]. St. Petersburg: St. Petersburg University Publ., 202.

14. Belozyorov, S. A. \& Pisarenko, Zh. V. (2014). Testirovanie rossiyskogo strakhovogo rynka na nalichie konvergentsii [Testing of the Russian insurance market for the convergence]. Ekonomika regiona [Economy of Region], 3, 198-208.

15. Raskov, N. V. (2009). Nenablyudayemaya ekonomika kak potentsialnyy resurs razvitiya rynochnogo khozyaystva [Nonobserved economy as a potential resource of the market economy development]. Problemy sovremennoy ekonomiki [Problems of modern economics], 2(30). Retrieved from: http://www.m-economy.ru/art.php?nArtId=2609 (date of access: 26.06.2015).

16. Gimpelson, V. E. \& Kapelyushnikova, R. I. (2006). (Eds). Nestandartnaya zanyatost $v$ rossiyskoy ekonomike [Nonstandard employment in the Russian economy]. Moscow: VShE Publ.

17. Sinyavskaya, O. V. (2005). Neformalnaya zanyatost v sovremennoy Rossii: izmerenie, masshtaby, dinamika [Informal employment in modern Russia: measurement, scales, dynamics]. Moscow: Nezavisimyy institut sotsialnoy politiki Publ.

\section{Authors}

Belozyorov Sergey Anatolyevich - Doctor of Economics, Professor, Economic Faculty, Department of Risk Management and Insurance, Saint-Petersburg State University (62, Tchaykovskogo St., Saint-Petersburg, 191123, Russian Federation; e-mail: beliksa@mail.ru).

Pisarenko Zhanna Viktorovna - PhD in Economics, Associate Professor, Economic Faculty, Department of Risk Management and Insurance, Saint-Petersburg State University (62, Tchaykovskogo St., Saint-Petersburg, 191123, Russian Federation; e-mail: janna12000@yandex.ru). 